\title{
Pain Nature
}

National Cancer Institute

\section{Source}

National Cancer Institute. Pain Nature. NCI Thesaurus. Code C21106.

The occurrence of the pain, whether it is incidental or continuous. 